\title{
$J M M$ UNRAM

\section{ANALISIS PENGARUH KOMPENSASI FINANSIAL DAN KOMPENSASI NON FINANASIAL TERHADAP KINERJA PEGAWAI PADA BADAN \\ PUSAT STATISTIK (BPS) PROVINSI NUSA TENGGARA BARAT}

\section{ISA $^{1}$}

AGUSDIN $^{2}$

\section{DJOKO SUPRAYETNO³}

This study aims to investigate the effect of financial and non-financial compensation, either partially or simultaneously, on the employee work performance of Central Bureau of Statistics of West Nusa Tenggara. The study also aims to determine the most dominant variablesinvestigated that affect the employee work performance. The study uses an associative-causal research approach aiming to reveal the relationship between two or more variables. Population of the study consisted of 68 people and they were taken entirely as a respondent. To collect data, a questionnaire instrument was used. Proir to the study, the instrument was tested todetermine its validity and reliability. Further, the study employed multiple linear regression with statistical test of determination (R2), t-test (partial test), F-test (simultaneous test), and individual coefficient of determination ( $r^{2}$ test). Result of the study show that: (1) Financial Compensation had no significant effect on the employee performance but non financial compensation did significantly influence the employee performance. (2) There was a significant effect of the simultaneous Financial Compensation and Nonfinancial Compensation on the Employee Performance. (3) The nonfinancial Compensation had indeed a dominant influence on the employee performance. For future research,it is suggested if the study analyzed the effect of compensation on employee performance, especially in government agencies that have earned remunisasi (Performance Benefit),future researchers not include financial compensation variables and add other variables that can affect the employee work performance such as employee behaviors, leadership style, working conditions, working environment, the complexity of task, and other similar others.From the theory of independent variables studied should be even more so that it can be seen that the dominant variable and the most dominant influence employee performance.

\footnotetext{
${ }^{1}$ MahasiswA Program Magister Manajemen Pascasarjana Universitas Mataram.

${ }^{2}$ Dosen Pembimbing Utama, Dosen Program Magister Manajemen Pascasarjana Universitas Mataram.

${ }^{3}$ Dosen Pembimbing Pendamping, Dosen Program Magister Manajemen Pascasarjana Universitas Mataram.
} 


\section{JMM JURNaL Macistrer MANAEEEN \\ UNIVERSITAS MATARAM \\ September 2015}

Keywords: Employees performances, Financial Compensation, Non Financial Compensation..

\section{PENDAHULUAN}

Sumberdaya Manusia (SDM) menjadi penggerak laju dinamika organisasi, sehingga baik buruknya suatu organisasi ditentukan oleh kinerja Sumber Daya Manusianya.Menurut Drucker (1998) seorang pakar manajemen terkenal mengemukakan bahwa tantangan bagi para manajer sekarang adalah tenaga kerja kini cenderung tak dapat diatur seperti tenaga kerja generasi yang lalu. Titik berat pekerjaan kini bergerak sangat cepat dari tenaga manual ke knowledge-worker yang menolak menerima perintah (komando) ala militer seperti cara yang diadopsi dunia bisnis 100 tahun yang lalu.

Hal ini juga sejalan dengan pandangan Bagis (2008), dunia kerja kontemporer menuntut adanya pergeseran paradigma mengenai tenaga kerja dimana para pekerja sekarang lebih ingin dihargai sebagai manusia yang terhormat dan bermartabat, karena bagaimanapun majunya teknologi saat ini, faktor manusia tetap memegang peranan penting bagi keberhasilan suatu organisasi. Sehingga SDM mempunyai peran sangat besar dalam kemajuan suatu organisasi.Dengan kata lainkinerja SDM di berbagai level dalam organisasi sangat menentukan kemajuan suatu organisasi.

Pernyataan tersebut diatas menyiratkan makna bahwa guna menunjang tujuan organisasi perlu didukung oleh SDM yang mempunyai kinerja baik, dan untuk menunjang kinerja karyawan yang dapat ditilik dari faktor kompensasi yang diberikan oleh organisasi.

MenurutMoeheriono (2009), definisi kinerja atau performance adalah hasil kerja yang dapat dicapai oleh seseorang atau sekelompok orang dalam suatu organisasi baik secara kuantitatif maupun kualitatif, sesuai dengan kewenangan dan tugas tanggung jawab masing-masing, dalam upaya mencapai tujuan organisasi bersangkutan secara legal, tidak melanggar hukum dan sesuai dengan moral maupun etika.

Pemikiran dari Sedarmayanti (2007)menyatakan suatu organisasi, baik pemerintah maupun swasta dalam mencapai tujuan yang ditetapkan organisasi hanya dimungkinkan karena upaya para pelaku yang terdapat didalam organisasi/perusahaan tersebut, dalam hal ini terdapat hubungan yang erat antara kinerja perorangan dengan kinerja lembaga/perusahaan, bila kinerja karyawan baik, maka kemungkinan besar kinerja perusahaan juga baik.Kinerja seorang karyawan akan baik bila dia mempunyai keahlian yang tinggi, bersedia bekerja karena digaji/kompensasi sesuai dengan perjanjian, mempunyai harapan masa depan yang lebih baik. Mengenai kompensasi dan adanya harapan merupakan hal yang menciptakan kesediaan melaksanakan kegiatan kerja dengan kinerja yang baik.

Untuk menjaga kinerja pegawai tetap tinggi maka faktor-faktor yang mempengaruhi kinerja pegawai menjadi perhatian manajerial dan organisasi karena tujuan peningkatan kinerja tidak hanya diperuntukkan bagi organisasi semata, akan tetapi bagaimana organisasi mampu memberikan kesejahteraan bagi pegawai menjadi sangat penting untuk diperhatikan. Seperti yang dinyatakan oleh Syafri Mangkuprawira (2002: 14) bahwa Manajemen Sumber Daya Manusia (MSDM) 


\section{$J M M$ UNRAM

merupakan penerapanpendekatan SDM dimana secara bersama-sama terdapat dua tujuan yang ingin dicapai, yaitu (1) Tujuan untuk perusahaandan (2)Untuk karyawan.Tentunya tujuanuntuk perusahaan diupayakan mampumeningkatkan kinerja perusahaan tersebut, sedangkan untuk karyawan hal ini diharapkan mampu mensejahterakan karyawan itu sendiri. Jika kepentingan yangsatu tercapai sedangkan yang lain tidak,maka pendekatan manajemen sumber daya manusia (MSDM) ini dinilai gagal.

Kesejahteraan karyawan akan tercapai apabila kebutuhan hidup yang mendasar terpenuhi baik untuk kebutuhan pangan, sandang, papan dan kebutuhan lainnya. Uang merupakan faktor yang sangat kuat dalam memenuhi kesejahteraan karyawan yakni uang yang diperoleh melalui kompensasi karyawan dalam bekerja.Kompensasi menurut pandangan Handoko (1989) adalah segala sesuatu yang diterima para karyawan sebagai balas jasa untuk kerja mereka. Menurut Efendi (2002), indikator yang dapat dijadikan penilaian kompensasi adalah, gaji, insentif, fasilitas dan tunjangan.

Walaupun para pegawai sudah semakin meningkat kesejahteraannya, khususnya pegawai BPS Propinsi Nusa Tenggara Barat (NTB), semestinya kinerja pegawai mencapai 100 persen dari target yang ditetapkan atasannya, karena adanya peningkatan pendapatan dari tunjangan kinerja kepada seluruh pegawai per bulan disamping gaji, fasilitas, insentif dan lainnyaNamun rata-rata capaian target pekerjaan perbulan masih dibawah 99,60 persen, bahkan mencapai kurang dari 96,50 persen, seperti yang ditampilkan pada tabel di bawah.

Kinerja yang masih belum optimal terlihat dari masih terlambatnya beberapa laporan hasil survey sehingga tidak dapat di laporkan tepat waktu.Dengan kondisi seperti diatas, apakah peningkatan kesejahteraan tidak mampu mendorong peningkatan kinerja pegawai.Mengapa capaian kinerja pegawai setiap bulan tidak mampu mencapai target 100 persen,mengapa masih banyak pegawai BPS Propinsi NTB yang terlambat masuk kerja bahkan tidak masuk kerja.Beberapa pertanyaan diatas perlu diteliti lebih mendalam untuk mendapatkan jawabannya.

Tabel 1.1. Capaian Kinerja Pegawai dan Tingkat Absensi Pegawai BPS Propinsi NTB Per Bulan Tahun 2013

\begin{tabular}{ccccc}
\hline No. & Bulan & $\begin{array}{c}\text { Tingkat } \\
\text { Ketidakhadiran } \\
(\mathbf{0})\end{array}$ & $\begin{array}{c}\text { Tingkat } \\
\text { Keterlambatan } \\
(\mathbf{0})\end{array}$ & $\begin{array}{c}\text { Kinerja } \\
\mathbf{( \% )}\end{array}$ \\
\hline $\mathbf{( 1 )}$ & $\mathbf{( 2 )}$ & $\mathbf{( 3 )}$ & $\mathbf{( 4 )}$ & $\mathbf{( 5 )}$ \\
1. & Januari & 1.60 & 7.35 & 98.96 \\
2. & Pebruari & 1.60 & 8.70 & 99.45 \\
\hline
\end{tabular}




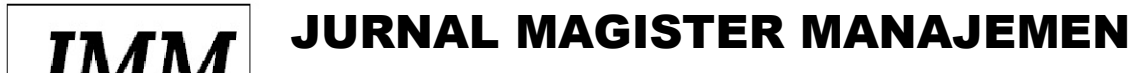 \\ UNIVERSITAS MATARAM \\ September 2015}

\begin{tabular}{clccc}
\hline 3. & Maret & 2.05 & 9.85 & 98.43 \\
4. & April & 2.81 & 9.27 & 99.55 \\
5. & Mei & 1.28 & 8.76 & 99.70 \\
6. & Juni & 1.98 & 12.02 & 97.42 \\
7. & Juli & 3.45 & 11.19 & 96.27 \\
8. & Agustus & 1.73 & 7.35 & 99.49 \\
9. & September & 2.05 & 7.67 & 99.75 \\
10. & Oktober & 1.09 & 5.50 & 99.56 \\
11. & November & 1.21 & 7.16 & 98.36 \\
12. & Desember & 1.02 & 7.16 & 99.45 \\
\multicolumn{2}{c}{ Rata-rata } & $\mathbf{1 . 8 2}$ & $\mathbf{8 . 5 0}$ & $\mathbf{9 8 . 8 6}$ \\
\hline
\end{tabular}

Sumber : Laporan CKP BPS Propinsi NTB 2013

Berdasarkan latar belakang di atas diperlukan kajian yang lebih mendalam tentang pengaruh Kompensasi Finansial dan Non Finansial terhadap Kinerja Pegawai di BadanPusat Statistik (BPS) Provinsi Nusa Tenggara Barat.

\section{Tujuan Penelitian}

Adapun tujuan dari penelitian ini adalah :

1) Untuk mengetahui apakah Kompensasi Finansial dan Non Finansial berpengaruh signifikan secara simultan terhadap Kinerja Pegawai BPS Provinsi NTB.

2) Untuk mengetahui apakah Kompensasi Finansial dan Non Finansial berpengaruh signifikan secara parsial terhadap Kinerja Pegawai BPS Provinsi NTB.

3) Untuk mengetahui manakah dari Faktor Kompensasi Finansial dan Non Finansial yang berpengaruh paling dominan terhadap Kinerja Pegawai BPS Provinsi NTB.

\section{Manfaat Penelitian}

Penelitian ini memiliki beberapa manfaat dalam beberapa bidang yang dapatdirumuskan sebagai berikut:

1) Manfaat Akademis

Secara akademis, penelitian ini dilaksanakan untuk memenuhi sebagian persyaratan dalam memperoleh gelar Magister Manajemen (MM) pada Program Pascasarjana Magister Manajemen Universitas Mataram;

2) Manfaat Teoritis

Penelitian ini memiliki manfaat dalam pengembangan ilmu pengetahuan bidang Manajemen Sumber Daya Manusia (MSDM) terutama terkait dengan teori kompensasi sebagai salah satu faktor yang mempengaruhi kinerja.

3) Manfaat Praktis

Adapun manfaat praktis dari penelitian ini adalah untuk memberikan sumbangan pemikiran kepada para pengambil keputusan (dalam hal ini Kepala Badan Pusat 


\section{TMM JURNAL MAGISTER MANAJEMEN UNIVERSITAS MATARAM September 2015}

Statistik Provinsi NTB, khususnya) dalam menentukan dan menyusun berbagai strategi dan kebijakan dalam meningkatkankinerja pegawainya.

\section{Landasan teori}

\subsection{Kompensasi}

Notoadmojo (2003 : 153) berpendapat, kompensasi adalah yangditerima oleh karyawan sebagai balas jasa untuk kerja mereka. Menurut Rivai dan Sagala (2009:741), kompensasi merupakan sesuatu yang diterima pegawai sebagai pengganti kontribusi jasa mereka pada perusahaan.Menurut Flippo dalamHasibuan (2009:119), Upah didefinisikan sebagai balas jasa yang adil dan layak diberikan kepada para pekerja atas jasa-jasanya dalam mencapai tujuan organisasi).Sedangkan menurut Sikula dalamHasibuan (2009:119), kompensasi adalah segala sesuatu yang dikonstitusikan atau dianggap sebagai suatu balas jasa atau ekuivalen).

Menurut Hasibuan (2009:118), kompensasi adalah semua pendapatan yang berbentuk uang, barang langsung atau tidak langsung yang diterima karyawan sebagai kompensasi atas jasa yang diberikan kepada perusahaan. Sementara menurut Werther dan Davis dalamHasibuan (2009:119), Kompensasi adalah apa yang seorang pekerja terima sebagai balasan dari pekerjaan yang diberikannya. Baik upah per jam ataupun gaji periodik didesain dan dikelola oleh bagian personalia).

Karyawan adalah setiap orang yang bekerja dengan menjual tenaganya (fisik dan pikiran) kepada suatu perusahaan dan memperoleh balas jasa sesuai dengan peraturan atau perjanjian. Besarnya balas jasa yang telah ditentukan dan diketahui sebelumnya, sehingga karyawan secara pasti mengetahui besarnya balas jasa/kompensasi yang akan diterimanya. Kompensasi inilah yang akan dipergunakan karyawan itu beserta keluarganya untuk memenuhi kebutuhankebutuhannya. Besarnya kompensasi mencerminkan status, pengakuan, dan tingkat pemenuhan kebutuhan yang dinikmati oleh karyawan bersama keluarganya.Jika balas jasa yang diterima karyawan semakin besar berarti jabatannya semakin tinggi, statusnya semakin baik, dan pemenuhan kebutuhan yang dinikmatinya semakin banyak pula.Dengan demikian, kepuasan kerjanya juga semakin baik.Di sinilah letak pentingnya kompensasi bagi karyawan sebagai seorang penjual tenaga, fisik dan pikiran (Hasibuan, 2009:117).

Kompensasi merupakan pengeluaran dan biaya bagi perusahaan.Perusahaan mengharapkan agar kompensasi yang dibayarkan memperoleh kompensasi prestasi kerja yang lebih besar dari karyawan.Jadi, nilai prestasi kerja karyawan harus lebih besar dari kompensasi yang dibayar perusahaan, supaya perusahaan mendapatkan laba dan kontinuitas perusahaan terjamin.Berdasarkan uraian di atas jelaslah pentingnya masalah kompensasi ini untuk karyawan dan perusahaan. Yoder dalam Hasibuan (2009:117), mengemukakan, The payment made to member of work teams for their participation, artinya balas jasa membuat anggota tim kerja dapat bekerja sama dan berprestasi. 
Tujuan pemberian kompensasi (balas jasa) antara lain adalah sebagai ikatan kerja sama, kepuasan kerja, pengadaan efektif, motivasi, stabilitas karyawan, disiplin, serta pengaruh serikat buruh dan pemerintah (Hasibuan, 2009).

a. Ikatan Kerja Sama. Dengan pemberian kompensasi terjalinnya ikatan kerja sama formal antara majikan dengan karyawan. Karyawan harus mengerjakan tugastugasnya dengan baik, sedangkan pengusaha/majikan wajib membayar kompensasi sesuai dengan perjanjian yang disepakati.

b. Kepuasan Kerja. Dengan balas jasa, karyawan akan dapat memenuhi kebutuhankebutuhan fisik, status sosial, dan egoistiknya sehingga memperoleh kepuasan kerja dari jabatannya.

c. Pengadaan Efektif. Jika program kompensasi ditetapkan cukup besar, pengadaan karyawan yang qualified untuk perusahaan akan lebih mudah.

d. Motivasi. Jika balas jasa yang diberikan cukup besar, manajer akan mudah memotivasi bawahannya.

e. Stabilitas Karyawan. Dengan program kompensasi atas prinsip adil dan layak serta eksternal konsistensi yang kompentatif maka stabilitas karyawan lebih terjamin karena turn over relatif kecil.

f. Disiplin. Dengan pemberian balas jasa yang cukup besar maka disiplin karyawan semakin baik. Mereka akan menyadari serta mentaati peraturan-peraturan yang berlaku.

g. Pengaruh Serikat Buruh. Dengan program kompensasi yang baik pengaruh serikat buruh dapat dihindarkan dan karyawan akan berkonsentrasi pada pekerjaannya.

h. Pengaruh Pemerintah. Jika program kompensasi sesuai dengan undang-undang perburuhan yang berlaku (seperti batas upah minimum) maka intervensi pemerintah dapat dihindarkan.

Simamora (2004: 442): “Kompensasi adalah apa yang diterima oleh para karyawan sebagai ganti kontribusi mereka pada organisasi". Selanjutnya menurut Simamora (2004:461)kompensasi finansial terdiri dari:

(a)Gaji/Upah

Definisi Gaji menurut Hasibuan (1999:133) adalah: :Balas jasa yang dibayar secara periodik kepada karyawan yang tetap serta mempunyai jaminan yang pasti".Pendapat serupa juga diungkapkan oleh Gitosudarmo (1995:299) yang menyatakan pengertian gaji adalah: "Imbalan yang diberikan oleh pemberi kerja kepada karyawan, yang penerimaannya bersifat rutin dan tetap setiap bulan walaupun tidak masuk kerja maka gaji akan tetap diterima secara penuh". Pembayaran gaji dilakukan setiap satu bulan sekali dimana karyawan menerima gaji berdasarkan tingkat jabatan, golongan, dan kontribusinya bagi perusahaan.

(b) Insentif

Jenis kompensasi lain yang diberikan kepada karyawan sebagai imbalan atas kerjanya adalah upah insentif. Perusahaan menetapkan adanya upah insentif untuk menghubungkan keinginan karyawan akan pendapatan finansial tambahan dengan kebutuhan organisasi akan peningkatan kualitas dan kuantitas 


\section{JMM JURNAL MAGISTER MANAJEMEN UNIVERSITAS MATARAM September 2015}

kerjanya. Menurut Nawawi (1997:317) definisi upah insentif adalah: "Penghargaan atau ganjaran yang diberikan untuk memotivasi para pekerja agar produktivitas kerjanya tinggi, sifatnya tidak tetap atau sewaku-waktu". Sedangkan Manulang (1994:147), "Insentif merupakan alat motivasi, sarana motivasi, sarana yang memberikan motif atau sarana menimbulkan dorongan".Di dalam instansi pemerintah daerah, insentif ini identik dengan istilah tunjangan kerja daerah.Di dalam instansi pendidikan insentif ini bisa dikenal sebagai tunjangan, karena tunjangan diharapkan dapat menjadi pendorong peningkatan kinerja pegawai Badan Pusat Statistik Propinsi NTB.

(c) Bonus.

Jenis kompensasi lain yang ditetapkan perusahaan adalah berupa pemberian bonus. Pemberian bonus kepada karyawan ini dimaksudkan untuk meningkatkan produktifitas kerja dan semangat kerja karyawan.Pengertian bonus menurut Simamora (2004:522) adalah "Pembayaran sekaligus yang diberikan karena memenuhi sasaran kinerja".Sedangkan menurut Sarwoto (1991:156), pengertian bonus adalah (a) Uang dibayar sebagai balas atas hasil pekerjaan yang telah dilaksanakan apabila melebihi target. (b) Diberikan secara sekali terima tanpa sesuatu ikatan di masa yang akan datang. (c) Beberapa persen dari laba yang kemudian dibagikan kepada yang berhak menerima bonus. Bonus diberikan apabila karyawan mempunyai profitabilitas atau keuntungandari seluruh penjualan tahun lalu.Penentuan besarnya pemberian bonus adalah berdasarkan kebijakan perusahan, tidak ada ketetapan yang pasti mengenai bonus yang diberikan.

(d)Honor kerja tambahan

Selanjutnya, Menurut Nawawi (2005:316) menambahkan aspek kompensasi finansial yaitu: Pembayaran kompensasi yang ditetapkan secara legal di luar pekerjaan tetap. Pembayaran kompensasi seperti ini dapat berupa pembayaran kompensasi diluar pekerjaan artinya pemberian balas jasa atas penyelesaian tambahan pekerjaan yang diberikan oleh atasan atau instansi.

Menurut Nawawi (2005:316) aspek kompensasi non finansial dapat berupa:

1) Perlindungan ekonomis terhadap bahaya atau kecelakaan merupakanjaminan pembayaran upah dalam jumlah tertentu selama suatu periode sepertitunjangan hari tua, tunjangan pengobatan atau asuransi kesehatan.

2) Program pelayanan karyawan merupakan ketersediaan pelayanan hiburan dan fasilitas kerja seperti rekreasi, perumahan, danfasilitas.

3) Program promosi/karir melibatkan rangkaian pilihan dari berbagai kesempatan. Tetapi dari sudut pandang organisasi, karir melibatkan proses dimana organisasi memperbaharui dirinya sendiri.

4) Pendidikan dan pelatihan merupakan ketersediaan kesempatan yang diberikan organisasi untuk mengikuti pendidikan dan pelatihan bagi pengembangan pegawai. 


\section{JMM JURNaL Macistrer MaNASEEEEN \\ UNIVERSITAS MATARAM \\ September 2015}

\subsection{Kinerja Pegawai}

Pengertian kinerja adalah hasil kerja secara kualitas dan kuantitas yang dicapai oleh seorang pegawai dalam melaksanakan tugasnya sesuai dengan tanggung jawab yang diberikan kepadanya. Wibowo (2010:7) menyatakan bahwa kinerja mempunyai makna yang lebih luas, bukan hanya hasil kerja, tetapi termasuk bagaimana proses pekerjaan berlangsung. Sedangkan Amstrong dan Baron (dalam Wibowo,2010:7) mendefinisikan kinerja sebagai hasil pekerjaan yang mempunyai hubungan kuat dengan tujuan strategis organisasi, kepuasan dan memberikan kontribusi pada ekonomi. Kinerja adalah tentang melakukan pekerjaan dan hasil yang dicapai dari pekerjaan tersebut.

Gomes (dalam Mangkunegara, 2010:9) mengemukakan definisi kinerja sebagai "Ungkapan seperti output, efisiensi serta efektivitas sering dihubungkan dengan produktivitas". Selanjutnya, menurut Mangkunegara (2010:10), "Kinerja karyawan (prestasi kerja) adalah hasil kerja secara kualitas dan kuantitas yang dicapai oleh seorang karyawan dalam melaksanakan tugasnya sesuai dengan tanggung jawab yang diberikan kepadanya".

Menurut Mangkunegara (2001:67) kinerja adalah hasil kerja secara kualitasdan kuantitas yang dicapai oleh seorang pegawai dalam melaksanakan tugasnyasesuai dengan tanggung jawab yang diberikan kepadanya.Tinggi rendahnyakinerja pekerja berkaitan erat dengan sistem pemberian penghargaan yangditerapkan oleh lembaga/organisasi tempat mereka bekerja.Pemberianpenghargaan yang tidak tepat dapat berpengaruh terhadap peningkatan kinerjaseseorang.

Menurut Gibson, (2008:123-124) faktor-faktor yang mempengaruhi kinerja adalah faktor dari variabel individu yang terdiri dari kemampuan dan keterampilan, latar belakang, dan demografis.Faktor yang mempengaruhi kinerja yang kedua adalah faktor dari variabel psikologi yang terdiri dari persepsi, sikap, kepribadian, motivasi, kepuasan kerja dan stres kerja.Sedangkan faktor yang ketiga yang mempengaruhi kinerja adalah faktor organisasi yang terdiri dari kepemimpinan, kompensasi, konflik, kekuasaan, struktur organnisasi, desain pekerjaan, desain organisasi.

Menurut Mahsun (2009:71), indikator kinerja (peformance indicator) sering disamakan dengan ukuran kinerja (performance measure).Namun sebenarnya terdapat perbedaan makna meskipun keduanya merupakan kriteria pengukuran kinerja.Indikator kinerja mengacu pada penilaian kinerja secara tidak langsung yaitu hal-hal yang sifatnya hanya merupakan indikasi-indikasi kinerja, sehingga bentuknya cenderung kualitatif.Sedangkan ukuran kinerja adalah kriteria kinerja yang mengacu pada penilaian kinerja secara langsung, sehingga bentuknya lebih bersifat kuantitatif.Indikator kinerja dan ukuran kinerja ini sangat dibutuhkan untuk menilai tingkat ketercapaian tujuan, sasaran dan strategi.

Sastrohadiwiryo (2001:235-236) memberikan uraian terhadap unsur-unsur yang harus dinilai dalam memberikan penilaian terhadap kinerja karyawan, yang dapat juga dinyatakan sebagai indikator-indikator dalam penilaian kinerja pegawai yaitu :

1) Kesetiaan. Kesetiaan yang dimaksudkan adalah tekad dan kesanggupan menaati, melaksanakan, dan mengamalkan sesuatu yang ditaati dengan penuh kesadaran dan tanggung jawab tekad dan kesanggupan tersebut harus dibuktikan dengan sikap dan perilaku tenaga kerja yang bersangkutan dalam kegiatan sehari-hari serta dalam melaksanakan tugas dan pekerjaan yang diberikan kepadanya. Kesetiaan 


\section{TMM JURNAL MAGISTER MANAJEMEN UNIVERSITAS MATARAM September 2015}

tenaga kerja terhadap perusahaan sangat berhubungan dengan pengabdiannya. Pengabdian yang dimaksud adalah sumbangan pikiran dan tenaga yang ikhlas dengan mengutamakan kepentingan publik di atas kepentingan pribadi.

2) Prestasi kerja. Prestasi kerja adalah kinerja yang dicapai oleh seseorang tenaga kerja dalam melaksanakan tugas dan pekerjaan yang diberikan kepadanya. Pada umumnya kerja seseorang tenaga kerja antara lain dipengaruhi oleh kecakapan, keterampilan, pengalaman, dan kesungguhan tenaga kerja yang bersangkutan.

3) Tanggung jawab. Tanggung jawab adalah kesanggupan seseorang tenaga kerja dalam menyelesaikan tugas dan pekerjaan yang diserahkan kepadanya dengan sebaik-baiknya dan tepat waktu serta berani memikul risiko atas keputusan yang telah diambilnya atau tindakan yang dilakukannya.

4) Ketaatan. Ketaatan adalah kesanggupan seseorang tenaga kerja untuk menaati segala ketetapan, peraturan perundaang-undangan dan peraturan yang berlaku, menaati perintah kedinasan yang diberikan atasan yang berwenang, serta kesanggupan untuk tidak melanggar larangan yang telah ditetapkan perusahaan maupun pemerintah, baik secara tertulis maupun tak tertulis.

5) Kejujuran. Kejujuran adalah ketulusan hati seseorang tenaga kerja dalam melaksanakan tugas dan pekerjaan serta mampu untuk tidak menyalahgunakan wewenang yang telah diberikan kepadanya.

6) Kerjasama. Kerjasama adalah kemampuan seorang tenaga kerja untuk bekerja bersama-sama dengan orang lain dalam menyelesaikan suatu tugas dan pekerjaan yang telah ditetapkan, sehingga mencapai daya guna dan hasil guna yang sebesarbesarnya.

7) Prakarsa. Prakarsa adalah kemampuan seorang tenaga kerja untuk mengambil keputusan, langkah-langkah atau melaksanakan sesuatu tindakan yang diperlukan dalam melaksanakan tugas pokok tanpa menunggu perintah dan bimbingan dari manajemen lininya.

8) Kepemimpinan. Kepemimpinan adalah kemampuan yang dimiliki seorang tenaga kerja untuk meyakinkan orang lain (tenaga kerja lain) sehingga dapat dikerahkan secara maksimum untuk melaksanakan tugas pokok. Penilaian unsur kepemimpinan bagi tenaga kerja sebenarnya khusus diperuntukkan bagi tenaga kerja yang memiliki jabatan seluruh hierarki dalam perusahaan.

\section{Kerangka Konseptual}

Berdasarkan uraian landasan teori di atas, maka dapat digambarkan kerangka konseptual penelitian ini sebagai berikut :

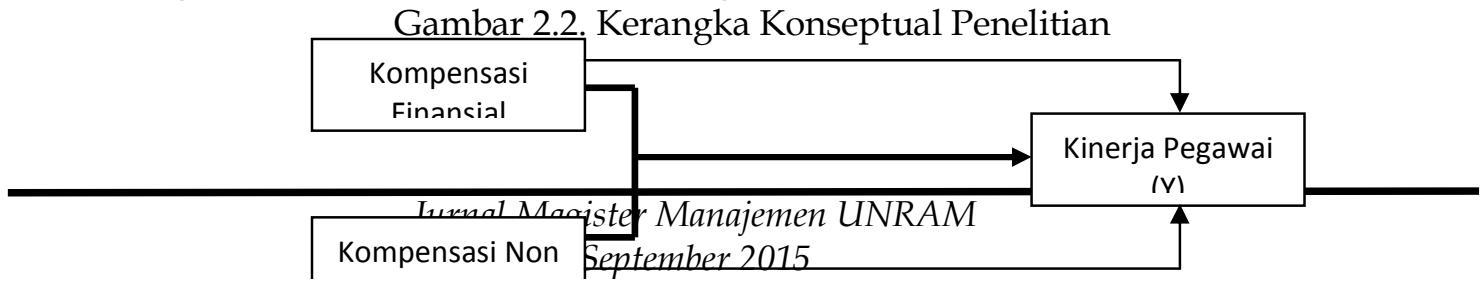




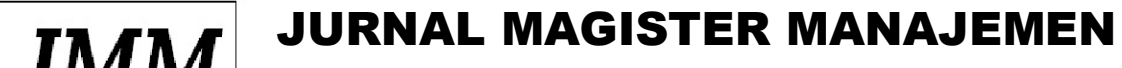 \\ UNIVERSITAS MATARAM \\ September 2015}

Keterangan $\longrightarrow$ Simultan

6. Hipotesis

Hipotesis merupakan jawaban sementara terhadap masalah penelitian yang secara teoritis dianggap paling mungkin dan paling tinggi tingkat kebenarannya.Adapun rumusan hipotesis yang diajukan adalah sebagai berikut :

1) Diduga terdapat pengaruh yang signifikan secara simultan dari Kompensasi Finansial dan Non Finansial terhadap Kinerja Pegawai BPS Provinsi NTB.

2) Diduga terdapat pengaruh yang signifikan secara parsialdari Kompensasi Finansial terhadap Kinerja Pegawai BPS Provinsi NTB.

3) Diduga terdapat pengaruh signifikan secara parsial dari Kompensasi Non Finansial terhadap Kinerja Pegawai BPS Provinsi NTB.

\section{METODE PENELITIAN}

\subsection{Jenis Penelitian}

Jenis penelitian yang digunakan dalam penelitian ini adalah penelitian asosiatif atau sebab akibat (kausal), yakni penelitian yang dilakukan dengan tujuan untuk mengetahui hubungan antara dua variabel atau lebih.Menurut Sugiyono (2008:5) "Penelitian asosiatif merupakan penelitian yang bertujuan untuk mengetahui hubungan antara dua variabel atau lebih.". Jadi disini ada variabel independen (variabel yang mempengaruhi) dan variabel dependen (variabel yang dipengaruhi)".Penelitian asosiatif merupakan penelitian dengan tingkatan tertinggi dibanding penelitian deskriptif dan komparatif.Dengan penelitian asosiatif dapat dibangun suatu teori yang berfungsi untuk menjelaskan, meramalkan dan mengontrol suatu gejala/fenomena, (Marzuki, C, 1999)dalam buku Metodologi Riset.Metode penelitian ini akan digunakan untuk mengetahui pengaruh variable independen/variabel yang mempengaruhi yaitu kompensasifinansial dan kompensasi non finansial sebagai variabel bebas terhadap kinerja pegawai sebagai variabel dependen/dipengaruhi.

\subsection{Populasi dan Responden Penelitian}

Populasi adalah gabungan dari seluruh elemen yang berbentuk peristiwa, hal atau orang yang memiliki karakteristik yang serupa yang menjadi pusat perhatian seorang peneliti karena itu dipandang sebagai sebuah semesta penelitian (Ferdinand, 2006). Sedangkan menurut Sugiyono (2002), populasi adalah wilayah generalisasi yang terdiri atas: obyek/subyek yang mempunyai kualitas dan karakteristik tertentu yang ditetapkan oleh peneliti untuk dipelajari dan kemudian ditarik kesimpulannya.

Dalam penelitian ini yang menjadi populasi adalah seluruh pegawai pada kantor BPS Provinsi NTB yang berjumlah 69 orang. Populasi dikelompokkan menjadi beberapa kelompok jabatan yaitu berdasarkan tingkatan eselon, seperti tabel berikut ini: 


\section{TM JURNAL MAGISTER MANAJEMEN UNIVERSITAS MATARAM September 2015}

Tabel 3.1. Jumlah Populasi Penelitian

\begin{tabular}{clc}
\hline No & Kelompok Jabatan & $\begin{array}{c}\text { Populasi } \\
\text { (orang) }\end{array}$ \\
\hline 1 & Eselon 2 & 1 \\
2 & Eselon 3 & 6 \\
3 & Eselon 4 & 20 \\
4 & Staf & 42 \\
& Jumlah & 69 \\
\hline
\end{tabular}

Sumber : BPS Propinsi NTB (diolah)

Mengingat jumlah populasi dalam penelitian ini relatif kecil yaitu sebanyak 69 orang, maka responden akan diambil seluruhnya sesuai dengan pendapat Gay dan Diehl (1992) bahwa sampel haruslah sebesar-besarnya,dalampenelitian ini dilakukan secara sensus. Pengertian sampling jenuh atau sensus menurut Sugiyono (2009:78) menyatakan bahwa sensus adalah teknik penentuan sampel bila semua anggota populasi digunakan sebagai responden.

Tetapi karena penilaian kinerja dinilai oleh atasan langsung maka jumlah responden penelitian ini sebanyak 68 orang sesuai dengan jumlah bawahan yang dinilai pada Tabel 3.2.dengan kata lain seluruh pegawai sebagai responden kecuali pimpinan tertinggi (Kepala BPS Propinsi NTB), karena kinerja kepala BPS Propinsi NTB penilaiannya dilakukan oleh Kepala BPS RI di Jakarta, hal ini tidak dapat peneliti lakukan mengingat keterbatasan waktu, birokrasi,dan jarak yang sangat jauh.

\subsection{Alat Pengumpulan Data}

Alat pengumpulan data yang digunakan dalam peneltian ini adalah daftar pertanyan (kuisioner) yang diberikan kepada responden. Menurut Silalahi (2010:296), "Kuisioner merupakan satu set tulisan tentang pertanyaan yang diformulasikan supaya responden mencatat jawabanya, alternatif ditentukan secara terbuka dan pertanyaan tentang pengaruh kompensasi finansial dan non finansial terhadap kinerja pegawai pada kantor Badan Pusat Statistik propinsi Nusa Tenggara Barat diberikan kepada seluruh pegawai untuk penilaian kompensasi finansial dan non finasial sedangkan untuk kinerja yang menialai adalah atasan langsung.

\section{HASIL PENELITIAN}

8.1. Uji Determinasi Simultan $\left(\mathbf{R}^{2}\right)$

Analisis Determinasi simultan dalam analisis regresi berganda digunakan untuk mengetahui persentase sumbangan pengaruh variabel dependent (X1 dan X2) 
secara serentak terhadap variabel dependent $(\mathrm{Y})$. Koefisien ini menunjukkan seberapa besar persentase variasi variabel independent yang digunakan dalam model mampu menjelaskan variasi variabel dependen. Sedangkan sisanya dijelaskan oleh sebab-sebab yang lain dari luar model.

Adapun hasil pengujian determinasi simultan $\left(\mathrm{R}^{2}\right)$ dapat dilihat pada tabel 4.12., di bawah ini :

Tabel 4.12. Hasil Uji Determinasi Simultan

\begin{tabular}{c|c|c|c|c}
\hline Model & $\mathrm{R}$ & $\mathrm{R}$ Square & $\begin{array}{c}\text { Std. Error of } \\
\text { the Estimate }\end{array}$ & $\begin{array}{c}\text { Durbin- } \\
\text { Watson }\end{array}$ \\
\hline 1 & $.487 \mathrm{a}$ & .237 & .45227 & 1.878 \\
\hline
\end{tabular}

a. Predictors: (Constant), Kompensasi Non Finansial , Kompensasi Finanasial

b. Dependent Variable: Kinerja

Sumber : Lampiran 3

Berdasarkan tabel 4.12., tersebut maka dapat digambarkan bahwa besarnya $R$ Square $\left(\mathrm{R}^{2}\right)$ adalah 0,237, hal ini berarti bahwa 23,7\% variasi Kinerja Pegawai dapat dijelaskan oleh variasi dari kedua variabel independen yaitu Kompensasi Finansialdan Kompensasi Non Finansial. Sedangkan sisanya 76.3\% (100\%-23,7\%) dijelaskan oleh sebab-sebab lain dari luar model yang tidak dimasukkan ke dalam model penelitian ini seperti kemampuan, keterampilan, latar belakang, demografis, persepsi, sikap, kepribadian, stres kerja, motivasi, kepuasan kerja, komitmen, budaya kerja, lingkungan kerja, sarana kerja, budaya kerja, kepemimpinan, konflik, kekuasaan, struktur organisasi, desain pekerjaan, desain organisasi, dan pengembangan karir.

\subsection{Analisis Uji Signifikansi Simultan (Uji F)}

Untuk melihat bagaimana pengaruh yang signifikan secara simultan dariKompensasi Finansial dan Kompensasi Non Finansial Terhadap Kinerja Pegawai Badan Pusat Statistik Provinsi NTB digunakan uji F. berikut disajikan hasil perhitungan uji $\mathrm{F}$.

Tabel 4.13. Hasil Perhitungan Uji F

\begin{tabular}{|c|c|c|c|c|c|c|}
\hline & & $\begin{array}{l}\text { Sum of } \\
\text { Squares }\end{array}$ & df & Mean Square & $\mathrm{F}$ & Sig. \\
\hline \multirow[t]{3}{*}{1} & Regression & 4,125 & 2 & 2,063 & 10,083 & ,000(a) \\
\hline & Residual & 13,296 & 65 & ,205 & & \\
\hline & Total & 17,421 & 67 & & & \\
\hline
\end{tabular}

a Predictors: (Constant), Kompensasi Non Finansial , Kompensasi Finanasial

b Dependent Variable: Kinerja

Sumber : Lampiran 3

Berdasarkan tabel 4.13., di atas diperoleh nilai $\mathrm{F}$ hitung sebesar 10,083. Kemudian, dengan menggunakan tingkat keyakinan 95\%, a =5\%, df1(jumlah variabel1)=2, dan df2 (n-k-1)=101-2-1=98, sehingga diperoleh hasil untuk $F$ tabel sebesar 


\section{$J M M$ UNRAM

3,1453 (pada lampiran 4). Sehingga oleh karena F hitung $>$ F tabel $(10,083>3,1453)$ maka dapat disimpulkan bahwa terdapat pengaruh yang signifikan secara simultan atau bersama-sama antara Kompensasi Finansial dan Kompensasi Non Finansialterhadap Kinerja Pegawai Badan Pusat Statistik Provinsi NTB.

\subsection{Analisis Uji Signifikansi Parsial (Uji t)}

Untuk melihat bagaimana pengaruh secara parsial dariKompensasi Finansial dan Kompensasi Non Finansialterhadap Kinerja Pegawai Badan Pusat Statistik Provinsi NTBdigunakan uji t. Dari informasi tabel 4.13., maka dapat dilihat bahwa nilai $t$ hitung positif untuk variabel Kompensasi Finansial sebesar 1,556 dan t hitung positif untuk Variabel Kompensasi Non Finansial sebesar 3,185. Untuk menemukan jawaban atas hipotesa yang ada maka perlu dibandingkan antara $t$ hitung dengan $t$ tabel.

Tabel 4.14. Hasil Uji t Pada SPSS 13.0

\begin{tabular}{llccccr}
\hline Model & & \multicolumn{2}{c}{$\begin{array}{c}\text { Unstandardized } \\
\text { Coefficients }\end{array}$} & \multicolumn{2}{c}{$\begin{array}{c}\text { Standardized } \\
\text { Coefficients }\end{array}$} & \multicolumn{1}{c}{ t } \\
\hline 1 & (Constant) & &, 740 &, 703 & & 1,053 \\
& Kompensasi Finanasial &, 208 &, 134 &, 185 & 1,556 \\
& $\begin{array}{l}\text { Kompensasi } \\
\text { Finansial }\end{array}$ & Non &, 594 &, 187 &, 379 & 3,185 \\
\hline
\end{tabular}

a Dependent Variable: Kinerja

Sumber : Lampiran 3

Dengan menggunakan tingkat keyakinan 95\% dimana alpa $=5 \%$, df (degree of freedom) n-k-1=68-2-1=65, sehingga diperoleh hasil untuk $\mathrm{t}$ tabel sebesar 1,998 (pada lampiran 3). Sehingga karena $t$ hitung Kompensasi Finansial $<$ t tabel $(1,556<1,998)$ maka dapat disimpulkan bahwa tidak terdapat pengaruh yang signifikan secara parsial dari Kompensasi Finansial Terhadap Kinerja Pegawai Badan Pusat Statistik Provinsi NTB.Sementara $t$ hitung untuk Kompensasi Non Finansial $>t$ tabel $(3,185>1,998)$ maka dapat disimpulkan bahwa terdapat pengaruh yang signifikan secara parsial dari Kompensasi Non Finansial Terhadap Kinerja Pegawai Badan Pusat Statistik Provinsi NTB.

\subsection{Analisis Uji r2 (Koefisien Determinasi Parsial)}

Uji $\mathrm{r}^{2}$ digunakan untuk melihat seberapa besar porsi pengaruh dari varibel independen terhadap variabel dependen secara parsial. Hasil uji $\mathrm{r}^{2}$ untuk koefisien determinasi parsial ini dapat dilihat berdasarkan standardized coeficient beta yang menunjukkan porsi pengaruh secara parsial setelah variabel intersep (konstan) ditiadakan dalam model. Hasil uji ini dapat dilihat pada tabeldi bawah ini.

Tabel 4.15. Hasil Uji $\mathrm{r}^{2}$ Pada SPSS 


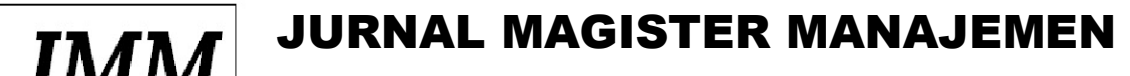 UNRAM

\begin{tabular}{ll}
\hline Model & $\begin{array}{l}\text { Standardized } \\
\text { Coefficients }\end{array}$ \\
\hline (Constant) & \\
Kompensasi Finanasial & 0,185 \\
Kompensasi Non Finansial & 0,379 \\
\hline
\end{tabular}

a. Dependent Variable: Kinerja

Sumber : Lampiran 3

Berdasarkan tabel 4.15., tersebut maka dapat digambarkan bahwa besarnya standardized coeficient beta untuk Kompensasi Finansial sebesar 0,185 dan Kompensasi Non Finansial sebesar 0,379. Hal ini menunjukkan bahwa variabel Kompensasi Non Finansial memiliki pengaruh yang dominan terhadap Kinerja Pegawai BPS Provinsi NTB.

\subsection{Interpretasi}

Berdasarkan analisa data yang telah dilakukan dapat di interpretasikan bahwa :

1) Koefisien regresi dari Kompensasi Finansial $\left(b_{1}\right)$ yang bernilai sebesar 0,208 berarti bahwa apabila variabel Kompensasi Finansial $\left(\mathrm{X}_{1}\right)$ ditambahkan ke dalam model, maka Kinerja Pegawai akan mengalami kenaikan sebesar 0,208. Koefisien regresi Kompensasi Finansial $\left(b_{1}\right)$ yang bernilai positif ini bermakna bahwa terjadi Pengaruh yang positif dari Kompensasi Finansial terhadap Kinerja Pegawai. Hal ini bermakna bahwa Kompensasi Finansial pegawai memiliki pengaruh yang positif terhadap Kinerja.

2) Koefisien regresi dari Kompensasi Non Finansial $\left(b_{2}\right)$ yang bernilaisebesar 0,594 menjelaskan bahwa apabila variabel Kompensasi Non Finansial $\left(\mathrm{X}_{2}\right)$ ditambahkan juga ke dalam model, maka Kinerja Pegawai akan mengalami kenaikan lagi sebesar 0,594. Koefisien regresi Kompensasi Non Finansial $\left(b_{2}\right)$ yang bernilai positif ini bermakna bahwa terdapat pengaruh yang positif dari Kompensasi Non Finansial terhadap Kinerja Pegawai. Hal ini bermakna bahwa Kompensasi Non Finansial berpengaruh positif terhadap Kinerja.

3) Berdasarkan uji F, diperoleh hasil untuk F tabel sebesar 3,1453 (pada lampiran 3). Sehingga oleh karena F hitung > F tabel $(10,083>3,1453)$ maka dapat disimpulkan bahwa terdapat pengaruh yang signifikan secara simultan atau bersama-sama antara Kompensasi Finansial dan Kompensasi Non Finansial Terhadap Kinerja Pegawai Badan Pusat Statistik Provinsi NTB. Hal ini senada dengan pendapat Gibson, (2008) bahwa "Imbalan dapat berpengaruh terhadap kinerja individu".

4) Berdasarkan hasil uji $t$, diperoleh $t$ hitung Kompensasi Finansial < $t$ tabel $(1,556<1,998)$ maka dapat disimpulkan bahwa tidak terdapat pengaruh yang signifikan secara parsial dari Kompensasi Finansial Terhadap Kinerja Pegawai Badan Pusat Statistik Provinsi NTB.Temuan ini menunjukkan bahwa meskipun ada pengaruh dari kompensasi finansial terhadap kinerja pegawai tetapi pengaruh ini tidak signifikan. Artinya bahwa, kompensasi yang diterima pegawai selama ini memiliki pengaruh yang positif tetapi tidak mampu meningkatkan kinerja pegawai. 


\section{$J M M$ UNRAM

Sementara $t$ hitung untuk Kompensasi Non Finansial $>t$ tabel $(3,185>1,998)$ maka dapat disimpulkan bahwa terdapat pengaruh yang signifikan secara parsial dari Kompensasi Non Finansial Terhadap Kinerja Pegawai Badan Pusat Statistik Provinsi NTB. Temuan ini menunjukkan bahwa kompensasi non finansial yang diterima pegawai selama ini memiliki pengaruh yang positif dan mampu meningkatkan kinerjanya baik di masa kini maupun di masa yang akan datang.

5) Berdasarkan uji $\mathrm{r}^{2}$ diperoleh nilai standardized coeficient beta untuk Kompensasi Finansial sebesar 0,185 dan Kompensasi Non Finansial sebesar 0,379. Hal ini menunjukkan bahwa Kompensasi Non Finansial memiliki pengaruh dominan terhadap Kinerja Pegawai Badan Pusat Statistik Provinsi NTB. Temuan ini mengindikasikan bahwa kinerja pegawai lebih ditentukan oleh kompensasi yang bersifat non finansial. Pegawai lebih menitik beratkan tujuan mereka bekerja adalah untuk lebih mengharapkan aspek pemberian pelayanan lebih oleh organisasi baik dari sisi program pelayanan karyawan, promosi, pemberian pelatihan maupun pendidikan, dan tunjangan hari tua. Hal ini sebagaimana pendapat dari Peterson dan Plowman dalam Hasibuan (2009:120), yang mengatakan bahwa "Orang mau bekerja karena hal-hal seperti keinginan untuk memiliki sesuatu, keinginan akan kekuasaan dan keinginan akan pengakuan".

\section{Kesimpulan}

Dari pembahasaan di atas, maka dapat diambil kesimpulan dari penelitian ini, antara lain :

(1) Terdapat pengaruh yang positif dan signifikan secara simultan dari Kompensasi Finansialdan Kompensasi Non Finansial terhadap Kinerja Pegawai Badan Pusat Statistik Provinsi NTB.

(2) Terdapat pengaruh yang positif tetapi tidak signifikan secara parsial dari Kompensasi Finansialterhadap Kinerja Pegawai Badan Pusat Statistik Provinsi NTB

(3) Terdapat pengaruh yang positif serta signifikan secara parsial dari Kompensasi Non Finansialterhadap Kinerja Pegawai Badan Pusat Statistik Provinsi NTB.

(4) Kompensasi Non Finansial memiliki pengaruh yang lebih dominan terhadap Kinerja Pegawai Badan Pusat Statistik Provinsi NTB.

\section{DAFTAR PUSTAKA}

.(1995),Kamus Besar Bahasa Indonesia, Jakarta : Departemen Pendidikan dan Kebudayaan Perum Balai Pustaka 


\section{$J M M$ UNRAM

.(2002), Keputusan Kepala Badan Pusat Statistik Nomor 003 Tahun 2002 Bab IV Pasal 47 Tentang Uraian Tugas Bagian, Bidang, Subbagian, dan Seksi Perwakilan BPS di Daerah, Jakarta : Badan Pusat Statistik

.(2010), Petunjuk Teknis (Juknis) Upah Kinerja, Jakarta : Badan Pusat Statistik

Ambar Teguh Sulistiyani dan Rosidah, (2003), Manajemen Sumber Daya Manusia, Graha Ilmu: Yogyakarta

Augusty, Ferdinand, (2006). Metode Penelitian Manajemen: Pedoman Penelitian Untuk Penulisan Skripsi, Tesis dan Disertasi Ilmu Manajemen. Badan Penerbit Universitas Diponegoro. Semarang.

Agus Eko Sujianto. (2009). Aplikasi statistik dengan SPSS 16.0, PT. Prestasi Pustaka Karya, Jakarta.

Dessler, Gary. (1997). Manajemen Sumber Daya Manusia. Jakarta: Prenhallindo.

Duwi Priyatno, SE (2008) dalam buku paham Analisis Statistik Data Dengan SPSS Yogyakarta : Mediakom

Drucker, Peter (1998). Peter Drucker on the Profession of Management Harvard Business

Flippo, B. E., (1993), Manajemen Personalia, Jakarta : Erlangga

Gibson, J.L, Ivancevich, J.M., Donnely, J.H, (2008), Organisasi : Perilaku, Struktur, Proses, Jilid 1 Edisi Ke-5 Terjemahan, Jakarta : Penerbit Erlangga

Ghozali, imam, (2011). Aplikasi Analisis Multivariate Dengan Program IBM SPSS 19, edisi kelima, Badan Penerbit Universitas Diponegoro, Semarang

Gitosudarmo, I dan I Nyoman Sudita. (1995).Perilaku Keorganisasian.Yogyakarta BPFE

Gay, L.R. dan Diehl, P.L. (1992), Research Methods for Business andManagement, MacMillan Publishing Company, New York

Handoko, T.H., (2011), Manajemen Personalia dan Sumberdaya Manusia, Edisi 2 Cetakan Kedelapan belas, Yogyakarta : BPFE-Yogyakarta

Hair (1995),Multivariate Data Analysis, Englewood Cliffs, New Jerseys

Hadari Nawawi (1997), Kepemimpinan Mengefektifkan Organisasi, Yogyakarta : Gajah Mada University Press

Handoko, T.H., (2011), Manajemen Personalia dan Sumberdaya Manusia, Edisi 2 Cetakan Kedelapan belas, Yogyakarta : BPFE-Yogyakarta 


\section{$J M M$ UNRAM

Hariandja, Marihot Tua Efendi. (2002). Manajemen Sumber Daya Manusia: Pengadaan, Pengembangan, Pengkompensasian, dan Peningkatan Produktivitas Pegawai. Jakarta: Grasindo.

Hasibuan, S.P. Malayu, (2009). Manajemen Sumber Daya Manusia, cetakan ketujuh Penerbit PT Bumi Aksara, Jakarta.

Mangkuprawira, (2002), Manajemen Sumber Daya Manusia Strategik, Penerbit Ghalia Indonesia, Jakarta

Hariandja, Marihot Tua Efendi, (2002), Manajemen Sumber Daya Manusia, Grasindo, Jakarta

M Manulang, (1994), manajemen Personalia, Cetaka 7, Ghalia Indonesia, Jakarta

Mahsun, (2006), Pengukuran Kinerja Sektor Publik.Yogyakarta : BPFE

Mangkunegara, A.A.A.P (2005), Evaluasi Kinerja SDM, Bandung: PT Revika Aditama

Mangkunegara, A. P. (2009). Manajemen Sumber Daya Manusia Perusahaan. (Cetakan Kesembilan). Bandung : PT. Remaja Rosdakarya.

Mathis, R.L., Jackson, J.H., (2001), Manajemen Sumber Daya Manusia, Jakarta : Salemba Empat

Moeheriono. (2009). Pengkuran Kinerja Berbasis Kompetensi.Bogor : Ghalia Indonesia

Marzuki. (2005), Metodologi Riset Panduan Penelitian Bidang Bisnis dan Sosial,Edisi Kedua, Ekosiana, Yogyakarta

Notoatmodjo, Soekidjo, (2003), Pengembangan Sumber Daya Manusia, Edisi Revisi, Cetakan Ketiga, Penerbit PT. Rineka Cipta, Jakarta

PB, Triton. (2007). Manajemen Sumber Daya Manusia .Tugu Publisher, Yogyakarta.

Robbins, Stephen, dan Timothy A., Judge, (2008), "Perilaku Organisasi, Organizational Behaviour", Buku Terjemahan, Jakarta : Gramedia.

Rivai, Veithzal. \& Sagala, E.J. (2009). Manajemen Sumber Daya Manusia untuk Perusahaan. Jakarta: Rajagrafindo Persada

Sedarmayanti, (2007) ,Manajemen Sumber Daya Manusia, Cetakan Pertama, Bandung : Refika Aditama 


\section{TMM JURNAL MAGISTER MANAJEMEN UNIVERSITAS MATARAM UNRAM September 2015}

Sarwoto, (1991). Dasar-Dasar Organisasi dan Management.Jakarta. Ghalia Indonesia.

Silalahi, U., (2010), Metode Penelitian Sosial, Bandung : PT Refika Aditama

Simamora Hendry (2004), Manajemen Sumber Daya Manusia, STIE, Yogyakarta

Siswanto Sastrohadiwiryo. (2001). Manajemen Tenaga kerja Indonesia, Pendekatan Administratif dan Operasional. Jakarta: Bumi Aksara.

Singgih Santoso, (2002), Statistik Multivariat, PT Elex Media Komoutindo, Jakarta Sudjana. (1990). Metode Statistika. Bandung: Tarsito

Sugiyono, (2008). Metode Penelitian Kunatitatif Kualitatif dan RED. Bandung Alfabeta.

Umar, Husein. (2005). Riset Pemasaran dan Perilaku Konsumen. Gramedia Pustaka Utama, Jakarta.

Wibowo, (2010), Manajemen Kinerja - Edisi Ketiga, Jakarta : PT. Raja Grafindo Persada

Wungu J. dan Brotoharsojo H., (2003), Merit System. PT. Raja Grafindo Perkasa. Jakarta. 